\title{
YELLOW-CROWNED NIGHT HERON A NEW BIRD FOR SASKATCHEWAN
}

FRANK BRAZIER, 2657 Cameron St., Regina, Saskatchewan, MANLEY CALLIN and DAVID CHASKAVICH

The Lebret Marsh is located 14 miles north of Indian Head in Section 36, Township 20, Range 13 West of the Second Meridian. It occupies the flat land north of the Qu'Appelle River where it flows between Mission Lake on the west and Katepwa Lake on the east. The marsh is bisected by a road which climbs the south wall of the valley.

We were standing on this road about 1530, on May 20, 1978, facing east watching some shorebirds with the sun smiling down from a cloudless sky. A large bird was flying towards us. It was not very high so we had only a head-on view but it was obvious that it was a heron. It was too small for a Great Blue Heron and too large for a Green Heron. At the angle of approach no white plumage could be seen which ruled out every heron except American Bittern, Little Blue Heron but immediately identified a Yellow-crowned Night Heron.

The bird altered course about 150 feet from us and headed south towards the river. The slate-gray body then became apparent which eliminated the bittern; the orange legs, white cheek patch on its dark head and the stout bill ruled out the Little Blue Heron but immediately identified a Yellowcrowned Night Heron in adult plumage.

When the bird reached the river it banked, altering course about $90^{\circ}$ to fly east down the river and then drop into the cattail bed on the north side. We drove across the bridge, followed a trail to its end, and proceded cautiously on foot through light woods to the river. A minute or two later the bird erupted from the cattails and flew north across the marsh, disappearing behind some bushes. We had a good view this time of the white crown, and the feet and lower tarsi projecting beyond the tail, although the latter is useful only when the immatures of the Yellow-crowned and Black-crowned Night Herons are being identified.

We drove back to the point of first observation, climbed through the fence and proceeded towards the north edge of the cattail bed. This time the bird was in a shallow depression screened by tall vegetation. It leaped into the air again before we could examine it at rest but we again noted the main recognition points, although it is such a striking bird that point recognition is hardly necessary. It flew low northeast and landed beyond the sewage lagoon. We drove and walked towards it but, once again, it flushed before we could see it at rest. it continued northeasterly until it vanished behind some trees, but we were close enough to note again all the recognition points: the stout dark bill, the white crown (the yellow is seldom seen unless quite close) and cheeks on the black head, the gray body and wings, the long dark streaking on the back, and the orange feet and legs projecting beyond the tail.

At no time did our bird make any sound. Because the sexes are alike we do not know if it was a male or female.

We can find no previous record of Yellow-crowned Night Herons occuring in Saskatchewan. Godfrey notes a breeding record in Ontario in May, 1954, and two records of wanderers in 
that province; nine records for the Maritimes and Newfoundland and a Manitoba record (May, 1959). ${ }^{2}$ There is also a summer, 1977, record for Oak Hammock Marsh in Manitoba.' There are three North Dakota occurrences: May and June, 1976, and June 1977..$^{6}$ 7 P. D. Skaar does not mention this bird nor does W. Ray Salt and Jim R. Salt, for Montana and Alberta, respectively. ${ }^{8}{ }^{4}$ Palmer shows the breeding range as southern midwest and southern states, north along the Atlantic seaboard to Massachusetts, as well as Mexico, Central and South America. ${ }^{3}$ The post-breeding dispersal (limits recorded in 1955) reaches northerly and westerly into areas adjacent to the breeding areas of North America. Palmer considers the North American subspecies to be extending its range northwards. ${ }^{3}$ Bull and Farrand agree. ${ }^{1}$
'BULL, JOHN, and JOHN FARRAND, JR. 1977. The Audubon Society field guide to North American birds, eastern region. Alfred A. Knopf, Inc., New York.

${ }^{2}$ GODFREY, W. E. 1966. The birds of Canada, Nat. Mus. Canada, Ottawa. Bull. 203

3PALMER, R. S. 1962. Handbook of North American birds, Vol. 1. Yale University Press, New Haven, Conn.

${ }^{4}$ SALT, W. RAY, and JIM R. SALT. 1976. The birds of Alberta. Hurtig Publishers, Edmonton.

${ }^{5}$ SERR, E. M. 1976. Northern Great Plains. American Birds 30:855-858.

${ }^{6}$ SERR, E. M. 1976. Northern Great Plains. American Birds 30:969-972.

TSERR, E. M. 1977. Northern Great Plains Region. American Birds 31:1151-1154.

${ }^{8}$ SKAAR, P. D. 1975. Montana bird distribution. Privately published, Bozeman, Montana.

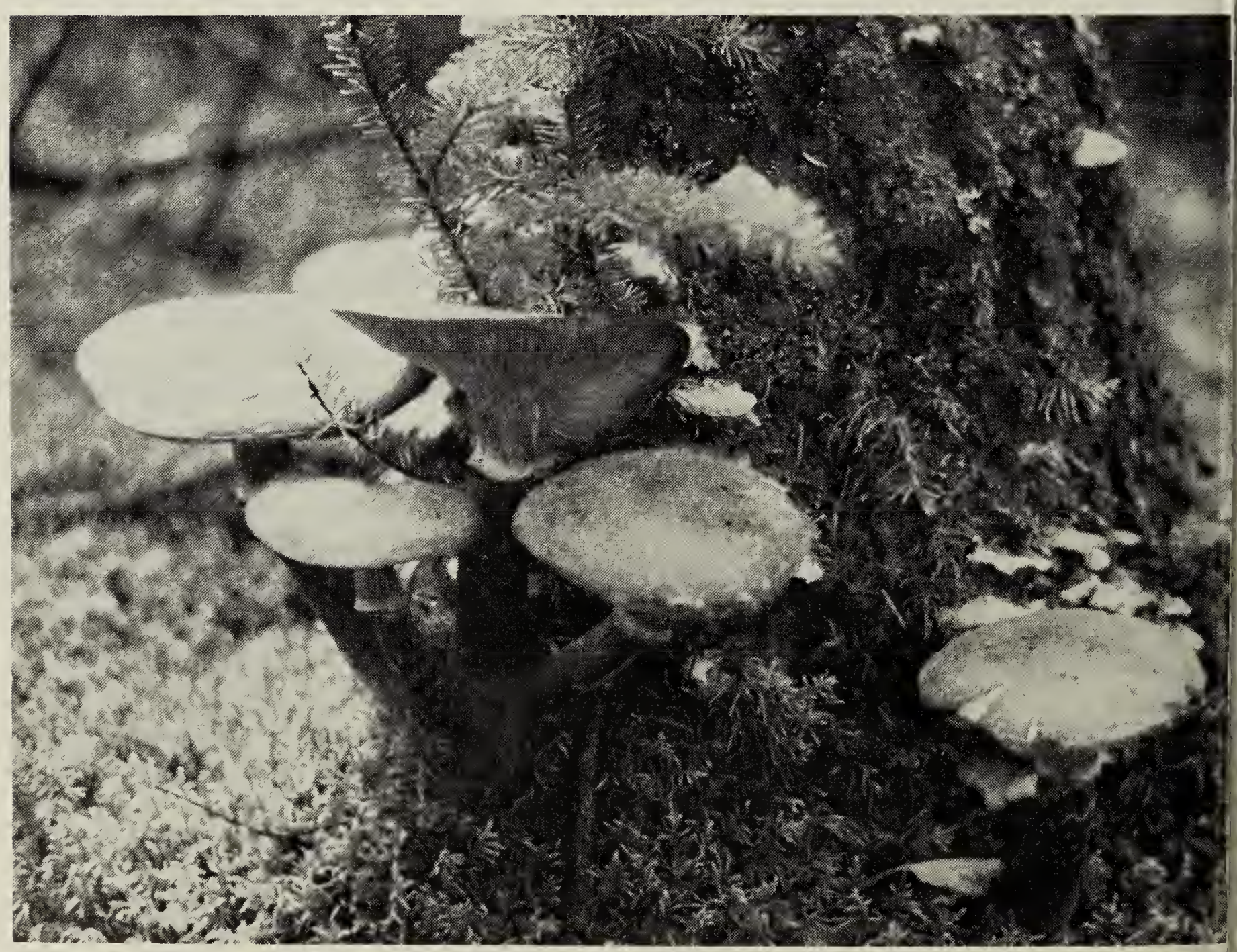

